\title{
LA PLUMA Y EL PINCEL DE SOR JUANA INÉS DE LA CRUZ
}

1. La representación iconográfica ha gozado históricamente de una gran tradición en el decurso de la historia de la literatura, pero posiblemente haya sido en el siglo XVII cuando esa tradición llegara a su momento culminante ${ }^{1}$. Muchos fueron los pintores de la época que cultivaron la "poesía muda" y apenas faltaron poetas que no ofrecieran su "elocuente pintura". Entre tantos, la poeta mexicana Sor Juana Inés de la Cruz rindió un excelente tributo a la revitalizada moda del retrato literario, pues en su corpus poético sobresalen no pocas composiciones iconográficas que la convirtieron en un obligado punto de referencia en el tratamiento y estudio de este género poético. La escritora fue uno de los más ilustres testimonios de los muchos creadores que en el siglo XVII concretaron poéticamente la tan anhelada aspiración de la interrelación artística entre poesía y pintura. El descontextualizado troquel horaciano del ut pictura poesis halló una feliz expresión literaria en los numerosos y excelentes retratos de la poeta mexicana.

Ha querido la fortuna crítico-literaria, con frecuencia tan tarda y torpe, que el excelente corpus de retratos literarios que nos legó la monja mexicana haya sido objeto de estudio ${ }^{2}$. Pero esa aproximación, con ser muy fructifera, no ha agotado definitivamente el tema y, entre los huecos que se aprecian, destaca una de las contribuciones satírico-burlescas que Sor Juana incorporó al género poético, y que pasa casi inadvertida para sus estudiosos; me refiero a la composición titulada Pinta en jocoso numen, igual con el célebre de Jacinto Polo, una belleza ${ }^{3}$. Este retrato literario en clave humoristica legado por Sor Juana es digno de ser analizado con algo más de atención, pues en ese poema iconográfico, a mi juicio, se aprecian algunas notas distintivas que podrian traducirse en la creación de nuevas perspectivas literarias de cara a la tradición del género poético en el que se inscribe $y$, por extensión, a todo lo que se deriva literariamente de la añeja formulación del tópico horaciano. Con esta modesta aportación al estudio de la poeta mexicana pretendo poner de manifiesto algunos de los méritos literarios que contiene el mencionado retrato poético, a la luz, claro está, del

1 Véase E. Orozco Diaz, Manierismo y Barroco, Madrid, Cátedra, $1981^{3}$, p. 52 , y pp. 191-211.

2 La critica ha prestado cierta atención a los poemas iconográficos de Sor Juana, pero cito tan sólo algunos de los trabajos que se han centrado prioritaria o exclusivamente en ese aspecto: S. G. Carullo, El Retrato Literario en Sor Juana Inés de la Cruz, New York, Peter Lang, 1991; W. H. Clamurro, "Sor Juana Inés de la Cruz reads her portrait", Revista de Estudios Hispánicos, 20:1 (Jan. 1986), pp. 27-43; Raúl Dorra, "El cuerpo ausente (Sor Juana y el retrato de Lisarda), NRFH, XLV, núm. 1 (1997), pp. 67-87; J. Greer Johnson, "A comical lesson in creativity from Sor Juana", Hispania, 71, núm. 2 (May, 1988), pp. 442-444; G. Sabat de Rivers, "Sor Juana: diálogo de retratos", Revista Iberoamericana, 120-121 (1982), pp. 703-713, "Sor Juana y sus retratos poéticos", Revista Chilena de Literatura, 23 (1984), pp. 39-52, "Sor Juana: la tradición clásica del retrato poético", en De la crónica a la narrativa mexicana, eds. M. H. Forster y J. Ortega, México, Oasis, 1986, pp. 79-93.

3 En Obras completas de Sor Juana Inés de la Cruz, ed. de A. Méndez Plancarte, México, FCE, 1951, I, pp. 320-330; las referencias textuales corresponden a esta edición. 
aludido poema de Jacinto Polo de Medina, cuyo explícito referente, desde la propia enunciación del título, tuvo que servir de alguna manera como modélico punto de partida ${ }^{4}$, junto a la entonces larga tradición de poesía iconográfica surgida como práctica poética inspirada en la profusa teoría emanada sobre todo de los humanistas italianos y de la posterior contribución española 5 .

Si en los muchos poemas iconográficos de Sor Juana se perseguía, entre otros fines, la alabanza de la figura representada -coincidiendo de esta forma con los objetivos de la poesía de la alta Edad Media y también con la de tradición petrarquista-, nuestro ovillejo -como los poemas aludidos del vate murciano- constituye, sin duda, una clara excepción a esta regla, pues se trata de una composición satírico-burlesca contra los artificios poéticos de la época y pone en solfa, por consiguiente, la tradición literaria, sobre todo la petrarquista, que a través del retrato lírico había proclamado la idealización de la belleza femenina.

Se habla de poema satírico-burlesco por el sentido general que tiene el troquel en la historia literaria; sin embargo, sin ánimo de profundizar en una cuestión tan compleja, que no tendria cabida en este trabajo y sobre la que aún no existe unanimidad, el poema de Sor Juana, a mi juicio, refleja con bastante claridad los rasgos de la parodia (respecto de su modelo más directo, Jacinto Polo de Medina, también de la tradición literaria que ha idealizado la belleza femenina, y de los parámetros convencionales de la retórica iconográfica; quizás precisamen-

4 El título del poema iconográfico de Sor Juana nos revela que nuestra autora tuvo que tener muy presente, en la elaboración de su poesía, la obra literaria de Jacinto Polo de Medina, quien tanta atención prestó a esta modalidad del retrato literario. Como ya sugirió Méndez Plancarte, Sor Juana pareció inspirarse en el poema del murciano titulado Retrata un galán a una mulata, su dama (Poetas líricos de los siglos XVI y XVII, ed. de A. de Castro, Madrid, BAE, 1951, vol. XLII, pp. 192-194), pero, sin duda, debió de hallar más aliento en su Fábula burlesca de Apolo y Dafne, y más especificamente en los versos de la descripción de Dafne, 16-204 (Poesía. Hospital de incurables, ed. de F. J. Diez de Revenga, Madrid, Cátedra, 1987, pp. 211-218); véase Emilie Bergmann, "La retórica del autorretrato en la poesia del Siglo de Oro", en M. A. Garrido Gallardo (ed.), Crítica semiológica de textos literarios, vol. II, Madrid, CSIC, 1986, pp. 231-238 y Art inscribed: Essays on Ekphrasis in Spanish GGolden Age Poetry, Cambridge, Massachusetts, Harvard University Press, 1979, en especial pp. 250-296. En cualquier caso, parece claro que tanto Polo de Medina como Sor Juana debieron de inspirarse en la genial Fábula de Píramo y Tisbe de Luis de Góngora (Obras completas, ed. J. e I. Millé, Madrid, Aguilar, 1972, núm. 74, pp. 202-214), que, sin duda, supuso un hito importante, entre otros aspectos, en la transgresión del retrato poético; véase R. Jammes, "Notes sur la Fábula de Píramo y Tisbe de Góngora", en Les Langues Néo-Latines, LV (1961), pp. 1-47; F. Lázaro Carreter, "Situación de la Fábula de Píramo y Tisbe, de Góngora" y "Dificultades en la Fábula de Píramo y Tisbe", en Estilo barroco y personalidad creadora, Madrid, Cátedra, $1984^{4}$, pp. $45-68$ y $69-76$.

5 Como es sabido, durante los siglos XVI y XVII, hubo una impresionante creación teórica -venida sobre todo de los humanistas italianos, aunque también hubo una considerable y respetable aportación española- que pretendía la fundamentación doctrinal en relación con el hermanamiento de las artes $\mathrm{y}$, en concreto, entre la poesía y la pintura. $\mathrm{Y}$, desde una perspectiva práctica, fueron muchos los poetas y pintores que rindieron su tributo a la elaboración de la "elocuente pintura" o de la "muda poesia". Entre los muchos estudios que se han hecho sobre el asunto, no podemos eludir la mención de los siguientes trabajos: A. Costa, "Las Décimas a Pedro Ragis de Carrillo y Sotomayor", Edad de Oro, VI (1987), pp. 35-49; A. Egido, "La página y el lienzo: sobre las relaciones entre poesia y pintura", en Fronteras de la poesia en el Barroco, Barcelona, Crítica, 1990, pp. 164197; J. Hagstrum, The Sister Arts. The Tradition of Literary Pictorialism and English Poetry from Dryden to Gray, Chicago, University of Chicago Press, 1958; P. O. Kristeller, El pensamiento renacentista y las artes, Madrid, Taurus, 1986; W. R. Lee, "Ut pictura poesis". La teoria humanistica de la pintura, Madrid, Cátedra, 1982; J. Matas Caballero, Juan de Jáuregui: Poesia y Poética, Sevilla, Diputación Provincial, 1990, pp. 93-120; E. Orozco, Temas del Barroco. De poesía y pintura, Granada, Universidad, 1947, Amor, poesía y pintura en Carrillo y Sotomayor, Granada, Universidad, 1968, "Lo visual y lo pictórico en el arte de Quevedo. (Notas sueltas para una ponencia sobre el tema)", en Academia Literaria Renacentista II. Homenaje a Quevedo, 1982, pp. 417-454. 
te por todo ello pueda verse también una cierta intención satírica respecto de los sistemas transgredidos), de lo burlesco (por el perfil y tono estilístico en el que destaca una pretensión humorística) y de lo grotesco (gracias a la diversidad y mixtura de los campos semánticos que la autora pone en relación para lograr la degradación definitiva de su imagen femenina $)^{6}$.

2. Si se desciende al texto, sin más dilación, se observa que el poema de Sor Juana $-y$ también el de Polo de Medina- es susceptible de ser dividido, conforme a la retórica clásica o tradicional, en tres partes: exordio, desarrollo y epilogo. La extensión, en número de versos, de cada una de esas partes resulta también bastante proporcionada en los dos textos: un larguísimo exordio; un epílogo muy breve; y un extenso desarrollo.

El exordio -no señalado explícitamente- de ambos poemas resulta, pues, bastante largo, lo que pudiera ser fruto del afán burlesco de sus autores respecto de los exordios poéticos de la época; de hecho, Sor Juana se burla en esta introducción, concretamente en los versos 141-160, de los largos exordios tan frecuentes en la poesía de su tiempo. Pero, tal vez, la función más característica e importante de ambos exordios sea la de señalar las pautas que seguirán los dos poemas; y puede afirmarse que en estos preliminares se aprecian ya claramente algunas diferencias importantes entre las dos composiciones iconográficas. En efecto, como era habitual sobre todo en los grandes poemas de la época, el autor marcaba en los primeros versos el propósito, el tema y el tono de la composición ${ }^{7}$. El objetivo y el tema del poema se nos muestra con claridad: se trata de un retrato literario, como concreta el empleo de la sinécdoque "pluma": "El pintar de Lisarda la belleza [...] se me viene a la pluma y a la mano" (vv. 1-4). La plena asimilación del viejo tópico del ut pictura poesis permite a Sor Juana la continua elusión del último concepto. Asimismo, la tradición literaria en la que se inserta e, incluso, su propia trayectoria poética, tan avezada y diestra en la creación de retratos literarios, le resulta lo suficientemente útil como para no insistir en la obvia ubicación del género poético que enmarca su composición.

La poeta afina aún más en la concreción de las pautas que va a seguir su poesía, pues, nos confirma incluso su estilo: "con un estilo llano" (v.3). Pero, si el propósito y el tema, el género, el tono, y aun el estilo, nos han sido revelados en el comienzo mismo del poema, Sor Juana nos descubre incluso la causa o el porqué que ha dado lugar a su composición. En el mismo exordio -aunque también a lo largo del poema-se aprecia cómo la autora nos ofrece algunas claves poéticas más de su composición, que adquiere, en algunos momentos, una elocuente función metapoética. Así, se observa cómo Sor Juana apela a la "locura" (v. 5), a la pérdida

6 En cualquier caso, sobre la controvertida cuestión del género o hibridación genérica entre sátira, buria y parodia pueden verse, entre otros, los siguientes trabajos: I. Arellano, Poesia satírico burlesca de Quevedo, Pamplona, EUNSA, 1984; C. Guillén, "Sátira y poética en Garcilaso", en El primer Siglo de Oro, Barcelona, Crítica, 1988, pp. 15-48; L. Hutcheon, "Ironie et parodie: stratégie et structure", Poétique, 36 (1978), pp. 467-477, "Ironie, satire, parodie. Une approche pragmatique de l'ironie", Poétique, 46 (1981), pp. 140-155; J. Iffland, Quevedo and the Grotesque, London, Tamesis, 1978; R. Jammes, La obra poética de Don Luis de Góngora y Argote, Madrid, Castalia, 1987; A. Pérez Lasheras, Fustigat mores. Hacia el concepto de la sátira en el siglo XVII, Zaragoza, Universidad, 1994 y Más a lo moderno (Sátira, burla y poesia en la época de Góngora), Zaragoza, Anexos de Tropelías, 1995; L. Schwartz Lerner, Quevedo: discurso y representación, Pamplona, EUNSA, 1987, Metáfora y sátira en la obra de Quevedo, Madrid, Taurus, 1983.

7 Recuérdese, a modo de ejemplo, el amplio muestrario de textos que, desde la Égloga I de Garcilaso, nos ofrece esa función metapoética en los versos iniciales que coinciden habitualmente con sus dedicatorias. 
del "juicio" (v. 14) como la única justificación posible que puede explicar su inclinación por ofrecer el retrato literario de Lisarda, a pesar de que ella, según su irónica confesión, no sabe nada de pintura. Ha sido, pues, una "locura" provocada por la tentación del "diablo" lo que la ha llevado a intentar pintar poéticamente (vv. 5-18) ${ }^{8}$. Pero, si recordamos la tradición literaria, basta con observar en estos versos la invocación a la "musa" (v. 12), o las alusiones a "la vena" (v. 35), la "locura" o la propia "tentación" (v. 14) del "diablo" (v.11), para confirmar su inclinación a favor de la tradición del ingenium poético. De esta forma, nuestra poeta establece una perfecta confabulación entre el sentido recto de la inspiración o del ingenium, que marca la pauta poética de la composición, y el sentido burlesco que imprime a su apelación y que le permitirá explicar la derivación humorística que va a seguir su retrato literario 9 .

En el exordio se aprecia también un rasgo que estará presente a lo largo del poema: la actitud titubeante de Sor Juana, quien intencionadamente nos hace caer en la sensación de su avance y retroceso, de su zigzagueo como estrategia perfectamente meditada que nos permite conocer los pasos seguidos en la elaboración del poema. En este sentido, la composición de Sor Juana termina adquiriendo una elocuente función metapoética al revelarnos sus coordenadas estéticas. El comienzo del poema se mueve entre la confirmación de su propósito de pintar a Lisarda por la locura que siente debido a la tentación diabólica y la necesidad de abandonar tal propósito al asumir su ignorancia de la técnica pictórico-poética. Si se quiere, y dicho con otros términos, nuestra autora oscila entre los conceptos de la polaridad ingenium/ars, es decir, siente la necesidad poética de pintar a Lisarda, pero no se cree capaz de llevar a buen puerto tal deseo (vv. 5-10).

Pero, si nos fijamos bien, en realidad, no existe tal conflicto, pues la dicotomía que nos suele presentar Sor Juana es tan sólo aparente. En los versos anteriores, resulta evidente que nuestra autora está invocando el tópico de la "falsa modestia" 10 , y sólo podemos entender que es una broma la supuesta admisión de su incompetencia: en primer lugar, porque difícilmente admitiremos que no sabe pintar literariamente quien, en su negación léxica -dice no conocer qué es "azul", "colorado", "regla", "pincel", "obscuro", "claro", y otros conceptos más específicos aún: "aparejo", "retoque", "reparo"- muestra un gran dominio de la técnica pictórica; en segundo lugar, porque sabemos que Sor Juana -en contra de sus propias palabras ("sin haber en mi vida dibujado")- tiene un extenso muestrario de retratos poéticos e, incluso, que había pintado varios retratos ${ }^{11}$. El aparente oxímoron, la enumeración de tér-

8 "She exploits - dice E. L. Bergmann- the dichotomy between verbal and visual art, and exaggerates the modesty-topos almost to the point of sacrilege, far beyond the bounds of decorum", Ant inscribed..., op. cit., p. 289.

9 La idea del poeta poseido siempre gozó de una larguísima tradición literaria, que desde Platón llegó hasta nuestros preceptistas del Renacimiento y del Barroco. La asimilación de la idea del furor poético llegó a expresarse incluso en términos hiperbólicos no exentos de humor, como vemos en el poema de Sor Juana. Véase sobre el tema los recientes trabajos de A. Egido, "La hidra bocal, sobre la palabra poética en el Barroco", Edad de Oro, VI (1987), pp. 79-113 (reimpr. en Fronteras de la poesia..., op. cit., pp. 9-55), y J. Roses, "Sobre el ingenio y la inspiración en la edad de Góngora", Criticón, 49 (1990), pp. 31-49.

10 Sobre el tópico de la falsa modestia, véase E. R. Curtius, Literatura europea y Edad Media Latina, México, FCE, $1984^{4}$ reimp., vol. I, pp. 127-131.

11 Sobre la posibilidad de que Sor Juana haya podido realizar algún retrato, véase A. Méndez Plancarte, Prólogo y notas, Op. cit., vol. I, y Octavio Paz, Sor Juana Inés de la Cruz o las trampas de la fe, Barcelona, Seix Barral, 1982, pp. 305-310. 
minos pictóricos, el aludido tópico de la falsa modestia, no son sino recursos retóricos que emplea Sor Juana para mostrar su táctica del titubeo, su supuesto conflicto entre el avanzar y el retroceder, entre el querer y no poder, entre el ingenium y el ars $^{12}$, que se resuelve habitualmente -como en este caso- a favor de los primeros términos de las ficticias dicotomías: "Yo tengo de pintar, dé donde diere, ${ }^{13} /$ salga como saliere,/aunque saque un retrato/tal, que después le ponga: aquéste es gato." (wv. 19-22).

La locura y la tentación diabólica para realizar el retrato es tan intensa, como demuestra la yuxtapuesta retahíla de términos que reitera enfáticamente su inclinación (“[...] esta tentación $[\ldots] /[\ldots] /$ ya no sólo me tienta, me pellizca,/me cozca, me hormiguea,/me punza, me rempuja y me aporrea"; vv. 14-18), que ni siquiera la posibilidad de fracasar en su empeño la distrae de su objetivo. Pues, en ese caso, tampoco sería ella la primera en fracasar, ya que antes hubo quien "con hurtos de sol y primavera/echa, con mil primores,/una mujer en infusión de flores;/y después que muy bien alambicada/sacan una belleza destilada,/cuando el hervor se entibia,/pensaban que es rosada y es endibia." (vv. 25-30).

La declaración de intenciones que la poeta nos muestra en el exordio desciende a un terreno más práctico y concreto al anunciar que renuncia a seguir el trilladísimo camino de escoger las flores para ponderar la belleza femenina, que ha sido tan común en el decurso de la historia literaria, y que se intensificó más aún con el desarrollo del petrarquismo. En efecto, la poeta mexicana se propone abandonar los hollados caminos poéticos y buscar nuevos senderos que terminen por enriquecer su expresión literaria. A este afán estético responde, pues, su renuncia a constreñir en un "ramillete" las excelencias de su dama. Poco importa que dicho florilegio sirviera para encarecer o para denostar las características de la mujer en cuestión, pues flores hubo para ambos propósitos. Lo interesante es que podamos apreciar el reto de Sor Juana de renunciar a una materia tan común en la tradición literaria a la que pertenece, como es la de la flor, y proponerse hallar nuevos materiales con los que ponderar los raros rasgos de Lisarda: "Mas no pienso robar yo sus colores; /descansen, por aquesta vez, las flores,/que no quiere mi musa ni se mete/ en hacer su hermosura ramillete.//Mas con qué he de pintar, si ya la vena/no se tiene por buena,/ si no forma, hortelana en sus colores, ${ }^{14} /$ un gran cuadro de flores?" (vv. 31-38).

12 La dicotomía ingenium/ars se había convertido para los teóricos del Barroco en el santo y seña que acompañaba toda reflexión sobre la esencia del fenómeno poético. A pesar de que la tendencia generalizada en el Barroco fue la proclamación de la superioridad del primer concepto, se estimaba necesaria la confabulación de ambos elementos para la consecución de una obra perfectamente equilibrada. Puede servir como botón de muestra la apelación de Jáuregui a la necesaria simbiosis de ambos conceptos: "Y como quiera que se arroje, el espíritu debe salir a salvo del peligro, que es todo el ser de las empresas; $y$ en las de poesia, tan dificil que pide gran fuerza de ingenio, estudios copiosos, artificio y prudencia admirable", Discurso poético, ed. M. Romanos, Madrid, Editora Nacional, 1978, p. 68. Para contextualizar, siquiera sea brevemente, la discusión barroca en torno a la dicotomía ingenium/ars, véase A. García Berrio, "El 'Patrón' renacentista de Horacio y los tópicos teórico-literarios del Siglo de Oro español", en Actas del IV Congreso Internacional de Hispanistas, Salamanca, Universidad, 1982, I, pp. 573-588.

13 A propósito de estos versos, E. Bergmann nos recuerda que Sor Juana recrea "una anécdota que utilizó Cervantes dos veces en el Quijote (II, iii y lxxi), el del mal pintor Orbaneja cuyo lema fue 'Dé donde diere", en art. cit., p. 236.

14 J. Polo de Medina aparece como el referente inmediato de esta alusión "hortelana" que nos remite al cromático florilegio que servía para encarecer la belleza femenina: "Mas no quiere mi amor hacerte ofrenda/Del color que se halla en cualquier tienda,/Y de flores, despojos de la mano/De cualquiera hortelano,/Que brotó la maceta/Del tierno 
La dificultad de su propósito es más ponderada aún, ya que en los siguientes ovillejos nuestra autora entona la palinodia de que todo ha sido ya escrito por la tradición literaria ("iOh siglo desdichado y desvalido/en que todo lo hallamos ya servido!", vv. 39-40), por los poetas anteriores que tuvieron el camino libre para la creación y gozaron la fortuna de ser ellos quienes podían acuñar conceptos e imágenes novedosos (vv. 45-488). En este sentido, también se ve cómo, una vez más, la poeta introduce una reflexión de carácter estético en su composición, pues parece situarse ante la dicotomía imitatio/inventio ${ }^{15}$, ya que -como vimos más arriba- Sor Juana se plantea la necesidad de buscar nuevos caminos poéticos, o sea, es partidaria de la inventio o de una imitatio creativa, en lugar de someterse a una mimesis servil que siga las pautas marcadas por la tradición literaria ${ }^{16}$. De hecho, la poeta mexicana, a continuación, se burla de la imaginería con que la tradición literaria, y de un modo especial la petrarquista, ha venido ponderando la belleza femenina, resultando absolutamente ridícula la repetición ad nauseam de unas imágenes y de un léxico que ya estaban definitivamente lexicalizados y carecían por completo de riqueza poética. Así, Sor Juana se sitúa, en los versos 49-94, en la tradición satírico-burlesca que venia poniendo en solfa la bisutería barata (cabello=oro, ojos=estrellas, labios=coral, dientes=perlas, boca=concha) y la marchita floresta (azucenas, rosas y claveles) del agotado petrarquismo ${ }^{17}$. La constatación de semejante pobreza poética confirma su idea expresada anteriormente de buscar nuevas formas poéticas y, por lo tanto, su decidida filiación a la inventio sobre la imitatio (vv. 95-102).

Sor Juana se dirige al lector a lo largo de su composición confesándole continuamente sus devaneos y dudas poéticas (como cuando se muestra consciente de haber abusado del uso de la palabra "pues", vv. 145-146; o del empleo de la palabra "principio") e, incluso, ofre-

casco de cualquier poeta". Pero habia sido Quevedo quien, con anterioridad, en su Aguja de navegar cultos, se habia burlado de los poetas de huerta en el sentido que ahora invocan nuestros autores: "Para las facciones de las mujeres hay gargantas de plata bruñida, y trenzas de oro para cabellos, y labios de coral y de rubies para jetas y hocicos, y alientos de ámbar (como pomos) para resuellos, y manos de marfil para garras, pechos de diamantes para pechos, y estrellas coruscantes para ojos, y infinito nácar para mejillas. Aunque los poetas hosrtelanos todo esto lo hacen verduras, atestando los labios de claveles, las mejillas de rosas y azucenas, el aliento de jazmines", en Quevedo esencial, ed. C. C. Garcia Valdés, Madrid, Taurus, 1990, p. 94.

15 En realidad, no se trataba de dos términos contrapuestos, pues en los Siglos de Oro se aceptaba sin ningún tipo de reserva la idea de la imitatio, pero entendida, no como imitación servil, sino como una imitación compuesta, como aclaró F. Lázaro Carreter ("Imitación compuesta y diseño retórico en la oda a Juan Grial", Anuario de Estudios Filológicos, II (1979), pp. 89-119); lo que ocurre es que, ya en el siglo XVII, el poeta, en su afán de admirar, conmover y deleitar al lector se encuentra en la necesidad de buscar nuevos senderos literarios, con lo que la inventio desplaza a la imitatio como fundamento teórico que posibilitará los anhelados deseos de novedad creadora (véase A. Egido, "La hidra bocal...", art. cit.). Véase también, entre otros, los siguientes trabajos: D. H. Darst, Imitatio (Polémicas sobre la imitación en el Siglo de Oro), Madrid, Origenes, 1985; A. Garcia Galiano, La imitación poética en el Renacimiento, Kassel, Reichenberger, 1992; V. Pineda, La imitación como arte literario en el XVI español, Sevilla, Diputación Provincial, 1994. un juego de retórica autoconsciente que tienen sus contradicciones internas, cuestiones de imitación y retórica, fuente parcial de la agudeza de estos poemas", en art. cit., p. 233. bastante similar al dirigirse contra los tópicos más manidos por el petrarquismo en la descripción suntuaria de los encantos de sus damas (zafiros y esmeraldas por ojos, diamantes por tez, perlas por dientes, rubies por labios, etc.). Véase $\mathbf{M}^{\mathrm{a}}$ P. Manero Sorolla, Introducción al estudio del petrarguismo en España, Barcelona, PPU, 1987, pp. 140-152. 
ciéndole la posibilidad de intervenir a su antojo en el poema: "si alguno halla otra voz que más expresa,/yo le doy mi poder y quíteme ésa" (w. 123-124) ${ }^{18}$.

Y no podía faltar la alusión al modelo más directo que Sor Juana tiene en cuenta a la hora de componer su poema: el poeta murciano Jacinto Polo de Medina, quien gozaba gran fama como poeta satírico-burlesco, y cuya poesía, en especial sus retratos poéticos, se habían convertido en obligada referencia para todo el que se introdujera en dicho género ${ }^{19}$. De hecho, la alusión explícita que hace Sor Juana a Polo de Medina pone de manifiesto que también ella, en cierto modo, lo tuvo presente, y en concreto sus retratos poéticos mencionados ${ }^{20}$.

$\mathrm{Si}$-de acuerdo con lo que acabamos de ver- en el poema de Sor Juana el exordio, entre otras cosas, sirve para explicitar las claves poéticas y fundamentos teóricos de su retrato literario, el del poema de Polo de Medina es útil también, en cierto modo, para la aclaración de fines similares, si bien es verdad que la profundidad y el fuste doctrinal que nos revela -aunque en forma de alusiones no exentas de ironía y ambigüedad- el poema de la mexicana parece estar ausente en el del murciano. Gran parte de su exordio nos muestra a un poeta que confiesa su amor a su amada acudiendo continuamente a los tópicos amorosos al uso, aunque en un tono humorístico que pone de manifiesto, en todo momento, el juego poético en el que se entrena nuestro autor, ajeno por completo a las sinceras convenciones amatorias. Así, declara el tiempo transcurrido sin ver a su amada, la búsqueda de un nombre poético, "dulce y blando", que armonice sincréticamente con sus cualidades y su sentimiento, y su confesión amorosa hilvanada con los manidos tópicos al uso, con un lexicalizado lenguaje amoroso que arranca de la trilladísima tradición del amor cortés y perpetuado en contrastes y antítesis igualmente heredados de la corriente petrarquista, pero todo ello combinado, eso sí, con un espíritu zumbón repleto de humor e ironía que termina por ridiculizar, no sólo su propia y personal escenita, sino los procedimientos estilísticos que vemos en la tradición de la poesía amorosa.

Finalmente, nuestro poeta, en los últimos versos del exordio, revela la causa que origina su retrato, concebido como ofrenda que sirve para lisonjear a su amada con la finalidad de vencer su desdén. Un retrato que, a diferencia del de la poeta mexicana, se recrea sólo en el rostro de su Teresa/Tertuliana, aunque contiene en tan breve muestra todas sus excelencias (vv. 74-77 y 86-87).

El cotejo con el poema de Sor Juana evidencia que el poeta murciano apenas si contiene alusiones a principios teóricos, ya fueran poéticos o pictóricos, salvo una simple alusión al conocidísimo troquel que evoca la clásica alusión al tópico del ut pictura poesis: "Con ingenio pintor y pincel pluma" (v. 79). Polo de Medina parece haber renunciado a fundamentar

18 En este sentido, se pone de manifiesto la estrategia del movere que perseguia el artista del Barroco, para lo que pretendía -como señaló J. A. Maravall- "introducir o implicar y, en cierto modo, hacer partícipe de la obra al mismo espectador. Con ello se consigue algo asi como hacerle cómplice de la misma: tal es el resultado que se obtiene con el procesamiento de presentarla abierta al espectador", La cultura del Barroco, Barcelona, Ariel, $1983^{3}$, p. 169.

19 Véase F. J. Díez de Revenga, Salvador Jacinto Polo de Medina (1603-1676), Murcia, Academia Alfonso X el Sabio, 1976; J. Barceló Jimènez, Polo de Medina: la sociedad y los tipos humanos en su obra, Murcia, Academia Alfonso X el Sabio, 1978.

20 Véase, más arriba, la nota 4. 
teóricamente su retrato -siquiera fuera con sencillas apelaciones-en beneficio de una ficción contextualizadora del mismo, cual es el ablandamiento de su rígida e ingrata amada -anécdota que lógicamente quedaba vedada a nuestra autora-, cuya historia amorosa se declara también, como el resto del poema, en un tono y un estilo satírico-burlesco. Nuestra poeta, en cambio, con su peculiar exordio se distancia no sólo de su inmediato modelo sino también de la práctica común en los retratos poéticos de la época, ya que no contextualiza su descriptio según la retórica tradicional de la poesía iconográfica y, además, otorga a su exordio una función metapoética que nos revela las claves literarias del poema y, al mismo tiempo, supone una evidente ruptura del sitema ${ }^{21}$, pues transgrede el papel del exordio según el paradigma del género iconográfico.

3. La descripción pictórica o el retrato literario de la dama nos sitúa en la segunda parte, es decir, en el desarrollo del poema, que abarca los versos 161-390. La autora nos muestra una descriptio que, de acuerdo con las convenciones retóricas de la tradición iconográfica, tiene un recorrido vertical y descendente, o sea que comienza en la cabeza y termina en los pies. Pero, siguiendo las pautas marcadas en el exordio, la poeta nos ofrece un retrato de Lisarda que no sólo se aleja del canon tradicional, sino que lo parodia abiertamente hasta situarse, incluso, en los límites de la misoginia literaria.

Pero, de cualquier modo, lo que resulta especialmente interesante es la forma en que nuestra autora lleva a cabo el plan pergeñado en el exordio, o sea, la constatación de la elaboración del retrato poético, la consecución del tono burlesco y los procedimientos usados para tal fin, la forma en que logra sortear la entonces larga tradición del retrato literario para conseguir una imagen inequivocamente distinta y, por lo tanto, nueva de la dama objeto de su pluma, y todo ello manteniéndose en la línea del prometido estilo llano.

Como se había visto en el exordio, en el retrato pictórico en sí de Lisarda se observa que la autora va contando en primera persona todo el proceso de realización, desde sus devaneos y titubeos hasta la concreción o resolución definitiva que adopta con la imagen seleccionada o la pincelada escogida. Este proceso de elaboración, ya sea interno o externo, es la base sobre la que se sustenta la composición, pues la vivifica de manera continua al explicitar la poeta sus pensamientos, sus dudas en el proceso de concreción del concepto deseado; o al dirigirse, en forma de apóstrofe, a un tú diverso y múltiple (la propia figura objeto del retrato, a la musa, pero sobre todo a los lectores, destinatarios del poema, y posibles censores), manteniendo asi no sólo su atención sino la tensión necesaria en el largo proceso de la elaboración del retrato; todos ellos interlocutores pasivos, silenciosos receptores de la autora, por ella vivificados y personificados, y gracias a ella convertidos en testigos mudos e impasibles, pero imprescindibles para el sostenido y vigoroso monólogo que la pintora escenifica -como un juego aparentemente dialógico- mientras nos ofrece las pinceladas maestras de su retrato poético. Y también, por qué no decirlo, con esta forma de proceder Sor Juana consigue dirigir la mirada del lector-espectador no hacia el cuadro sino hacia su propia mano. La humana mano de la divina pintora-escritora se convierte, así, en la verdadera protagonista

21 Véase C. Bousoño, Teoria de la expresión poética, Madrid, Gredos, $1976^{6}$, vol. I, pp. 492-572. 
del conjunto compositivo, con lo que la joven poeta mexicana logra enaltecer su propia figura poético-pictórica que brilla fulgorosamente por su capacidad demiúrgica ${ }^{22}$.

Por su parte, el poeta murciano había optado en su Retrato por ofrecernos igualmente un monólogo con la apariencia de mantener un pseudodiálogo con su amada y destinataria del poema-retrato. Ese tú, apostrofado pero impenitentemente mudo, mantenía así la coartada literaria de la ficción amorosa, aunque fuera en clave satírico-burlesca. La ingrata Teresa -0 Tertuliana- es, pues, la receptora e interlocutora del poeta-pintor porque es ella el objeto de su poema-pintura y su finalidad amorosa. Y si el "tú" confirma la coherencia interna en el poema de Polo de Medina, el tácito "vosotros"/"ustedes", o sea los lectores/censores, son los destinatarios a los que Sor Juana ha convertido en apostrofados interlocutores y que sustentan el supuesto y aparente diálogo que hábilmente monologa la poeta mexicana, como hiciera con anterioridad el poeta murciano en su Fábula de Apolo y Dafne. Esta forma pronominal conviene perfectamente a la estrategia poética de Sor Juana, ya que nosotros sus lectores somos los testigos que tendremos que certificar si la poeta-pintora ha conseguido retratar el raro prodigio que representa la extraordinaria Lisarda. Por ello, la joven poeta mantiene un monólogo continuado o un pseudodiálogo con su propia musa o con sus hermanos lectores, que son los que sirven para ponderar su creación poética y valorar su condición de escritora.

El retrato pictórico ${ }^{23}$ o la descriptio de la dama solía comenzar por el cabello, como hace nuestra autora en su lineamento -"Por el cabello empiezo, esténse quedos" (v. 161)-, aunque la distancia de la modélica tradición idealista se producirá tan sólo lo que tarde en "pintar" todos sus "enredos" (v. 162), refiriéndose no a los provocados por el cabello de Lisarda, sino a las supuestas asociaciones que su sola mención evocarian. La lastimosa realidad de la modelo llega hasta el extremo de hacer que la propia retratista dude irónicamente de sus posibilidades expresivas: "no hallo comparación que bien les cuadre:/ique para poco me parió mi madre" (vv. 163-164). La tradición petrarquista podría brindar las imágenes oportunas: “¿Rayos de sol?". Y se responde a sí misma la autora: "Ya aqueso se ha pasado,/la pregmática nueva lo ha quitado" (vv. 165-166); y por qué no "¿Cuerda de arco de amor, en dulce trance?", y se contesta también que "eso es llamarlo cerda, en buen romance" (vv. 167-168). En ambos casos, Sor Juana renuncia al socorro de la tradición idealista, en el primero, porque ella es consciente de su total agotamiento, y en el segundo, se permite hacer un juego de palabras gracias a la disemia de "cerda" que le aconseja evitar su empleo para no caer en la descalificación en lugar del elogio. Pero, la realidad es que ni la agudeza ni el ingenio de nuestra

22 Recuérdese el trabajo de J. Lara Garrido en el que destaca la capacidad demiúrgica del poeta-pintor que crea su poema-retrato: "Los retratos de Prometeo (Crisis de la demiurgia pictórica en Paravicino y Góngora)", Edad de Oro, VI (1987), pp. 133-147. En efecto, la poeta no está interesada en ofrecernos el retrato poético final de Lisarda, sino en mostrarnos todo su proceso creativo, con sus vacilaciones y aciertos, con su rechazo y asimilación de la tradición literaria, de manera que, más que el retrato, el tema de la composición es la propia poeta en pleno proceso de creación literaria, convertida en una verdadera reflexión metapoética.

23 Las lógicas limitaciones de este tipo de trabajos me obliga a fijarme sólo en algunos rasgos físicos del retrato poético de Sor Juana: el cabello, la frente, las cejas y los ojos, que pueden resultar suficientes para ejemplificar el proceder poético seguido en su paródica descriptio. 
autora podía salvar el escollo que le presentaba su modelo; y desde luego, el infinito repertorio de la tradición petrarquista para la alabanza del cabello tampoco podia disponer del concepto adecuado para su Lisarda. Así que lo mejor sería acudir a otras fuentes más cercanas, como el lenguaje coloquial, o el refranero: "iQué linda ocasión era/de tomar la ocasión por la mollera!" (vv. 169-170). En efecto, incluso en el proceso de degradación de la belleza femenina era oportuno comenzar por la cabeza porque, además, "la ocasión la pintan calva" (vv. 171-178).

Pero el ingenio de nuestra autora le permite usar el motivo del cabello -"nacido", es decir, y gracias a su sentido disémico, "a propósito"-, no ya para ponderar la calvicie o el postizo de Lisarda ("que es lo que encarecerse más se puede", v. 184), sino para, otorgándole una función metapoética, referirse a su propia composición e, incluso, se permite una irónica autocritica aprovechando el valor disémico que le proporciona la palabra "Escritura", pues confiesa su ignorancia en ambas materias, la religiosa y la literaria: "El de Absalón viniera aquí nacido,/por tener mi discurso suspendido;/mas no quiero meterme yo en hondura,/ni en hacerme que entiendo de Escritura." (vv. 179-182). En efecto, del mismo modo que Absalón, el hijo de David, que había conspirado contra su padre, en su huida, se le enredó su larga cabellera en las ramas de un árbol y se quedó suspendido, así se encuentra nuestra autora con su poema, una vez retratado el asunto del cabello. Resulta interesante, por otra parte, comprobar una vez más cómo Sor Juana recurre al campo religioso para extraer imágenes o alusiones que ilustren su retrato literario (recuérdese la alusión al "diablo") y, como en este caso, elevan el tono en un sentido más cultista.

El siguiente peldaño que desciende toda descriptio de la dama debe detenerse, como hace ahora Sor Juana, en la frente: "y bájese a la frente mi reparo;/gracias a Dios que salgo a lo claro,/que me pude perder en su espesura,/si no saliera por la comisura" (vv. 185-188). El retrato físico de la mujer avanza al mismo tiempo y compás que la propia composición y, en este sentido, resulta imposible no hallar una conexión evidente entre los rasgos de la dama que se mencionan y su aplicación al propio poema. Así, se aprecia que la autora se alegra de haber descendido a lo "claro" porque se halla en la frente y se pudo haber perdido en la "espesura" de la peluca de no haber salido deslizándose por su craneo ("comisura"). El valor dilógico de esos versos nos permite, como decimos, aplicarlo a la composición: Sor Juana se alegra de haber vuelto hacia lo "claro", es decir, al estilo llano que había anunciado, ya que de haber continuado con el tono cultista que le había impuesto la alusión a los cabellos de Absalón, podria haberse perdido en la espesura y en la hondura de la oscuridad poética.

La poeta-pintora nos muestra una visión burlesca de la frente basándose en una imagen hiperbólica, pues la asocia con una larga "caballería", que en las Indias podía significar "cierto repartimiento de tierras o haciendas" (Auts.). Pero el valor dilógico de "caballería" le permite continuar el juego de palabras, ya que, en su sentido recto, sabemos que las tierras estarían "aradas", por lo que, Sor Juana, en su habitual apóstrofe a los lectores, les sugiere que no teman, puesto que las caballerias, en este caso, al referirse a la frente de Lisarda, corresponden al cielo, es decir, a su sentido metafórico, y no al suelo, con lo que la extensísima frente de la dama está "limpia y despejada" (vv. 189-194). 
A cada paso, Sor Juana vuelve sobre su poema, como si temiera apartarse de las pautas señaladas en el exordio. De ahí que, de nuevo, volvamos a encontrar otros versos que cumplen una evidente función metapoética puesto que en ellos reflexiona la autora acerca del estilo de su composición: "iQué apostamos que ahora piensan todos,/que he perdido los modos/del estilo burlesco,/pues que ya por los cielos encarezco?/Pues no fue ese mi intento, /que yo no me acordé del firmamento,/porque mi estilo llano,/se tiene acá otros cielos más a mano;" (vv. 195-202). Todo parece indicar que nuestra autora es consciente, en momentos determinados, de que ciertas imágenes pueden resultar difíciles con lo que su incomprensión provocaría no sólo su alejamiento del estilo llano, sino también la pérdida del tono burlesco. De ahí que en estos versos, siguiendo el hilo común de la palabra "cielo" o "firmamento", resuelva la cuestión asociando el término a una parte del cuerpo de la dama (la boca y la frente), como resultaba tan común en la poesía de la época.

El retrato sigue, a continuación, por las cejas, que inspiran a la poeta-pintora un juego de palabras, puesto que lo habitual en la poesía de la época es asociarlos a la imagen de los "arcos", y una palabra que rima en consonante con "arcos" es "zarcos", que significa de color azul claro, con lo que el retrato azulado de Lisarda por seguir el efecto paronomástico no sólo resultaría ridículo sino que, incluso, se asociaria a algún demonio, cuyo color se suponía azulado (vv. 207-212). En la tradición idealista de la poesía áurea las cejas se asociaban habitualmente a los arcos; el reto de nuestra autora -como venimos observando-consiste en hallar una imagen novedosa que siga el tono y el estilo propuesto (vv. 217-220). Así, a través de la pregunta retórica, Sor Juana niega que se pueda tratar de cualquiera de los dos arcos por antonomasia, ni el de Cupido, ni el que se deduce de la metáfora siguiente, el arco iris. Las cejas de Lisarda responden a una imagen novedosa, como sugiere la poeta (“iMe dirán que esto es viejo y es trillado?", v. 224), y sobre todo hiperbólica -que es uno de los recursos fundamentales para la consecución del sentido burlesco-, lejos de toda sugerencia mítica o idilica, pues sus arcos son los de una "cañería".

Sor Juana nos ofrece ahora el retrato o la descriptio de los ojos de Lisarda. Los primeros versos (wv. 229-235) que dedica la poeta al motivo reflejan su aparente titubeo y dificultad para dar con la imagen o la comparación certera que lo muestren con fidelidad. Y, a continuación -como ha ocurrido con otras partes del cuerpo-, la autora evita explícitamente comparar los ojos con las imágenes más tópicas y lexicalizadas que nos ha llegado de la tradición literaria (w. 236-244). En efecto, la imagen habitual con la que se asocian los ojos es la del sol, término que, aplicado en su sentido recto a los ojos, seria obviamente una exageración; de ahí que Sor Juana recurra otra vez al terreno religioso para burlarse de su posible desliz; y escarmentada en la experiencia ajena, de acuerdo con el refranero popular (si bien, la poeta actúa sobre el refrán según sus necesidades expresivas cambiando "barbas" por "luces"), echa sus luces en remojo y se olvida de pretender una imagen obtenida de ese lexicalizado campo semántico. Pero el tono burlesco continúa teniendo una base lingüística y, así, junto a la derivación, el juego de palabras resulta útil a nuestra autora para reírse de su tentación "solariega", cuya disociación le permite referirse a que ella no ha querido -como sabemos- recurrir al entorno semántico de "sol" ("solar-"), ya que hubiera significado su caída en la tradición literaria (es decir, "solariega") que procuraba evitar. 
Una vez que ha renunciado al arsenal más común del que derivan las imágenes que puedan alabar los ojos de su dama, nuestra autora nos ofrece una visión de sí misma confesándose incapaz de hallar la comparación o el símil adecuado (vv. 245-247). Tras haberlo intentado, Sor Juana parece abandonar la posibilidad de hallar las imágenes y símiles para los ojos, a pesar de que se trata de la parte más alabada del cuerpo femenino por la tradición literaria, en concreto por la petrarquista, pues en los ojos se fijaba el reflejo del alma y eran a su vez "manantial de perfecciones" (v. 255). Sin embargo, Sor Juana ha renunciado a ofrecer una imagen degradada de la faceta espiritual de Lisarda, y se recrea sólo y exclusivamente en el plano corporal. Nuestra poeta se invita a sí misma a concluir el retrato de los ojos: "razón es ya que salgan de madrina,/pues a sus niñas fuera hacer ultraje/querer tenerlas siempre en pupilaje./En fin, nada les cuadra, que es locura/al círculo buscar la cuadratura." (vv. 258-262). El sentido humorístico se nos muestra cuando vemos el valor disémico de las palabras clave. Así, "madrina" nos remite a la propia poeta; "niñas" alude a los propios versos, además de a las niñas de los ojos; y "pupilaje" se refiere a las pupilas de los ojos y a la labor de tutela que tienen las madres y, en este caso, la "madrina", es decir, la autora. De esta forma, tenemos de nuevo ocasión de comprobar cómo Sor Juana nos ha hecho pasar del retrato físico de la dama al plano metapoético, pues está aludiendo a la propia composición y, en un sentido más genérico, a la obra literaria, ya que ésta debe desprenderse del tutelaje de su autor y seguir su propia peregrinación en manos de los lectores. Por último, la renuncia de Sor Juana a seguir con el motivo de los ojos se nos antoja definitiva, de ahi el tono expeditivo que se deriva de los versos con los que concluye su descriptio, basándose en la derivación de "cuadro" y su antítesis con "círculo", que es la metonimia con la que evoca los ojos ${ }^{24}$.

4. El poema de Polo de Medina también se cierra con un epilogo final (vv. 314-327) en el que el poeta recurre a unas argumentaciones voluntariamente perogrullescas y redundantes que enfatizan el tono satírico-burlesco mantenido a lo largo del poema. Muestra a su ingrata amada su retrato ("traslado") diciéndole que él ha reflejado el original, con lo que no debiera extrañarse de su producto artístico, y sus posibles faltas. Y como había declarado en el exordio, el poeta-pintor espera que su amada se ablande de cara a su solicitud amorosa al entregarle su retrato, y con un léxico típico del amor cortés le comenta de forma reiterativa y obvia las consecuencias de su rígido desdén.

Finalmente, Sor Juana también termina, a manera de epílogo, el retrato de Lisarda. Lejos de entonar la palinodia solicitando perdón por haber transgredido los cánones de belleza femenina que ha heredado de la tradición literaria, la poeta-pintora nos recuerda, de nuevo, a través de la imagen religiosa, que, al fin y al cabo, no ha sido la ley cristiana la sometida al potro de su pluma: "A nadie cause escándalo ni espanto,/pues no es la ley de Dios la que quebranto" (wv. 389-390). Y, por último, nos comunica la escasa edad de la dama retratada ("veinte años

La transgresión y la parodia del retrato de la dama es acentuada, en los versos siguientes, por Sor Juana al fijarse en la caricaturización de unos rasgos que no resultaban tan frecuentes en la tópica descriptio: nariz, garganta, mano, cintura, pie e, incluso, el vestido y la peluca, como una prolongación fisica que potencia el efecto esperpéntico de la mujer. 
de cumplir en mayo acaba", v. 395), la rúbrica que certifica la autoría del retrato - "Juana Inés de la Cruz la retrataba", v. 396- y proclama su satisfacción y orgullo por el poema realizado, convirtiéndose ella misma definitivamente en el verdadero centro de interés del poema.

5. Una vez visto el poema-retrato de Sor Juana, conviene analizar, siquiera sea brevemente, cuál es la herencia recibida del aludido Jacinto Polo de Medina. Veamos, pues, los paralelismos y diferencias entre ambos poemas iconográficos, considerando tan sólo los versos que nos centran en sus respectivos retratos. En principio, los dos poemas siguen el paradigma habitual de las composiciones iconográficas que persiguen la descripción o pintura del ideal femenino de belleza -aunque en ambos casos se persiga la inversión de dicho paradigma-: es decir, siguen un proceso vertical descendente al fijar los rasgos corporales de la mujer retratada.

Así, vemos que el recorrido corporal que realizan los dos poetas es casi idéntico, teniendo en cuenta que mientras que Polo de Medina fijaba su retrato en el rostro de la dama, Sor Juana nos ofrecía el retrato completo de Lisarda:

- Polo de Medina: cabello, frente, cejas, ojos, pestañas, nariz, mejillas, boca, labios, dientes.

- Sor Juana: cabello, frente, cejas, ojos, nariz, mejillas, boca, garganta (y continúa con la mano, cintura, pie, vestido).

Esta diferencia en el planteamiento global del retrato de ambos poetas confirma, de nuevo, la voluntad de la poeta mexicana de apartarse de su precedente, eligiendo todo el cuerpo de su dama como objetivo de su retrato. Pero esa desemejanza en su pretensión poético-pictórica no es óbice para hallar un espíritu y aliento ciertamente común en ambos escritores, pues los dos pretenden componer un poema iconográfico en el que inviertan los rasgos de la ideal belleza femenina que han heredado de la tradición literaria, y en especial de la corriente petrarquista. Por lo tanto, el proceder de los dos poetas resulta muy similar, ya que ambos transgreden la tradición del poema iconográfico para construir un retrato satírico-burlesco del retrato femenino, con lo que pretenden invertir la imaginería suntuaria que idealizaba cada uno de los aspectos de la mujer.

Si las coincidencias afectan, en gran medida, al espíritu, al objetivo y al tema de ambos retratos, también podemos apreciar que hay semejanza en el estilo llano que imprimen a sus textos y que contribuye adecuadamente a las pretensiones comunes del retrato satírico-burlesco que anhelan realizar.

A pesar de que hay aspectos y elementos comunes en los dos poemas, no se debería caer en la simplificación de pensar que es consecuencia de la imitación realizada por Sor Juana. Las coincidencias de ambos textos se deben a que los dos autores han procedido de forma muy similar, a saber: han transgredido la tradición literaria del retrato femenino ideal para obtener una imagen satírico-burlesca de la descriptio y, en esa pretensión, su procedimiento ha buceado en la tradición petrarquista que es, sin duda, la corriente que enriqueció y perfeccionó la belleza ideal de la mujer. Por lo tanto, las similitudes de ambos poemas radican en que sus dos autores actuaron sobre el mismo paradigma. De hecho, una rápida lectura de los dos poemas revelaria que sus coincidencias se concretan tan sólo en los materiales y referentes, en general, que sustentan, en el modelo recto, la idealización de las partes del cuerpo de la mujer; pero, una vez 
seleccionada la base común para la imaginería, la consecución de la metáfora satírico-burlesca que degradaria la belleza femenina se materializa de forma muy distinta. Así, podemos observar que sus semejanzas proceden sobre todo del arsenal común legado por la tradición literaria, en especial por el petrarquismo -y, por supuesto, por el antipetrarquismo- que se había centrado en los astros, la pedrería suntuaria, la floresta, y en todos los casos con las consiguientes y respectivas asociaciones a una amplia panoplia cromática ${ }^{25}$.

Pero, observemos siquiera sea de forma rápida, en el siguiente cuadro sinóptico, la manera de proceder de ambos poetas respecto de la tradición literaria para apreciar lo que une y separa a sus dos poemas iconográficos, partiendo tan sólo del fragmento común de ambos retratos, o sea del rostro de Teresa y de Lisarda, respectivamente ${ }^{26}$ :

POLO DE MEDINA

SOR JUANA

\section{CABELLO}

sol, rayos

oro

amarillo, rubio

cuerda, arco

hebras, madeja bayos, azabache, prietos

morcillas

moño, guedejas

sortijas, sabandijas

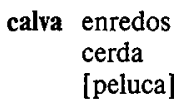

Absalón (func. metapoét.)

\section{FRENTE}

cielo

estrellas

cristal

leche

nieve

blanca

CEJAS

arcos de Cupido

arco iris

(Función metapoét.) medianoche

pecas

mulato

entintada

ollin, azabachada

negra-parda

triunfales

turquescos

negras

cerdas, hilo

fluecos

tenacillas, hoces,

corvillas

guarda-polvo

epitetos [añejos]

\author{
claro \\ comisura \\ caballería \\ limpia \\ despejada
}

arcos de cañería zarcos viejo y trillado

25 Véase Ma $\mathrm{P}$. Manero Sorolla, Imágenes petrarquistas en la lírica española del Renacimiento. Repertorio, Barcelona, PPU, 1990.

26 El siguiente cuadro sinóptico nos permite comprobar, de forma muy resumida, la realización del retrato poético de Polo de Medina (columna segunda) y de Sor Juana (tercera columna) respecto de cada una de las partes del cuerpo de la dama que aparecen en la primera columna. En ésta reseño las partes del cuerpo y sus características serias aludidas por los dos poetas (las de Sor Juana están en cursiva) y transgredidas posteriormente. 
OJOS

estrellas

cielo

luceros

soles

esferas

globos

rutilantes

doradas

arreboles

serenos

manantial perfec.

niñas

párpados

pestañas

Apolo

(Func. metapoét.)

NARIZ

cañón de plata

zona

cañón de vellón

corvo caño alambre

estaño

nogal

enebro

almendruco

fundas de nieve

\section{MEJILLAS}

aurora
maravillas
carmin, rojas
grana
rosa
cándidas

(func. metap.)

BOCA

puente [func. Vitales]

rubi

nácar

coral

concha

clavel

grana

Aurora

perlas orient.

diamantes

garganta

nieve, blanca

hueso

amarillos, blancos sol

(func. metapoe.) solariega solar

\section{cuadratura del círculo}

niñas-pupilaje

buñuelos, pimienta, alucinados luces en remojo

\section{tortizosa}

seguida

sin geómetra madrugada

dos mentiras

ébano

nevados pomos/romos

romos

jarcia vana, hortelano

sangriento Brasil

hueso

carne

madroño

camuesa

[escupitajo]

salada

cecina

colorada

garapiñada 
Como se aprecia, en la construcción conceptística -que es la base de los dos poemas iconográficos- de ambos autores se observan ciertas e importantes diferencias, pues mientras que Polo de Medina tiende a la acumulación de imágenes satírico-burlescas, como pretendiendo dar respuesta, en clave humoristica, a cada una de las imágenes legadas por la tradición literaria, Sor Juana tiende a la reducción y, en sentido contrario a la aportación exhaustiva de distintas imágenes contrafacta, procura simplificar la asociación de ideas de modo que cada una de las partes del cuerpo femenino sea pintada metafóricamente con una sola imagen burlesca, que, en todo caso, se ovilla a sí misma sugiriendo, a partir de ella, nuevas ideas que hiperbolizan satíricamente la ya de por sí degradada imagen.

Con esta manera de proceder, se aprecia que la construcción metafórica del poeta murciano se atiene más a los trillados senderos del antipetrarquismo y procura oponer una imagen satírico-burlesca a cada una de las conocidas imágenes que ha seleccionado de la tradición literaria. El procedimiento de la poeta mexicana se me antoja algo más complejo porque su esfuerzo compositivo se sitúa más allá de la simple objeción de carácter antipetrarquista, pues, en lugar de contradecir las múltiples imágenes de la tradición literaria, y específicamente la petrarquista, la joven monja busca una sola imagen, un único concepto que, de forma contundente, consiga la anhelada caricatura de la parte corporal de la mujer objeto de la descriptio. Se trata, pues, frente a la amplificatio que persigue Polo de Medina, de alcanzar una concentración léxica y metafórica a partir del hallazgo oportuno, el concepto. Y ese proceso de simplificación y condensación poética tiene que lograr, al menos, el mismo efecto depreciador que se consigue con la imagen satírico-burlesca de la belleza femenina alcanzada con la enumeración y acumulación de imágenes, con lo que el esfuerzo de nuestra poeta se centra en la búsqueda y hallazgo de un concepto que contenga una gran riqueza semántica, cuya capacidad de sugerencia en su afán degradador iguale y supere los efectos satírico-humorísticos logrados por la vía de la enumeración acumulativa de imágenes-eco del anti-petrarquismo.

La actuación y procedimiento de Sor Juana se sitúa, de esta forma, en la línea del más puro conceptismo, de acuerdo con la vieja formulación de Gracián, quien define el concepto como "un acto del entendimiento, que exprime la correspondencia que se halla entre los objectos" 27 . Así, pues, el ejercicio de nuestra autora, de manera simplificada, se traduce en la búsqueda de un concepto original, distinto y distante de sus dos modelos, el directo-Polo de Medina-, y el indirecto - la tradición literaria-, cuya transgresión desea; y, de este modo, cuanta más distancia exista entre las ideas asociadas u objetos relacionados, mayor será su riqueza expresiva y, por tanto, su valor poético. El concepto hallado deberá permitirnos comprender y comprobar su efecto satírico-burlesco respecto del canon petrarquista y la superación o distanciamiento del modelo antipetrarquista tomado como referente inmediato.

En su anhelo de lograr este propósito, nuestra poeta contaba con un extenso corpus de figuras retóricas tradicionales, entre las que ha elegido -como hemos visto- aquellas que han sido susceptibles de convertirse en agudezas propiamente dichas de acuerdo con la filosofía gracianesca, gracias a la actuación de un rasgo esencial: la dificultad, que constituye el

27 B. Gracián, Agudeza y arte de ingenio, ed. E. Correa Calderón, Madrid, Castalia, 1969, I, p. 55. 
alma del concepto. En este sentido, podemos apreciar que Sor Juana sigue las pautas del discurso de Gracián, de manera que su procedimiento conceptístico se emplea principalmente en la creación de agudezas de concepto (a través del empleo de la metáfora, la alegoría, la hipérbole, la ironía, la metonimia) y agudezas verbales (con el uso de la dilogía o disemia, derivación, disociación, paronomasia). Además, ha sabido explotar acertadamente otros procedimientos estilisticos de base fundamentalmente lingüística: el aumentativo, las jergas (lenguaje eclesiástico o religioso, retórico, científico, etc.), un léxico vulgar -pero renunciando al empleo del taco, el insulto o el lenguaje chocarrero- felizmente mezclado con el uso de cultismos, el refrán y la frase hecha o el cliché ${ }^{28}$.

En este poema encontramos la mixtura de lo conceptista "llano" con su más rico y culto conceptismo; la más depurada creación léxica se pone al servicio de un tono y una finalidad satírico-burlesca. La combinación de estilos y de concepciones estéticas sobresalen nítidamente en nuestra composición, ofreciendo una evidente diversidad tonal bajo una misma finalidad poética: la proclamación de su capacidad literaria. Así, nuestra autora no tuvo el menor reparo en afiliar tácticamente su poema entre los que seguían el estilo llano. Y, lejos de considerar que se trataba de un pronunciamiento en relación con la guerra de los estilos literarios -lo que hubiera sido paradójico al provenir de una de las más enfáticas deudoras del mal llamado "culteranismo" 29 -, sólo nos cabe entenderlo como la acertada respuesta que Sor Juana daba al decoro poético, pues la poeta mexicana tal vez pretendia llevar la coherencia poética hasta su último extremo estableciendo un estrecho paralelismo entre todos los elementos estructurales del poema. De ahí que la simple alusión a su "estilo llano" esté repleta de una carga metapoética importante, como, de hecho, irradiaba a lo largo de todo el texto.

En efecto, el poema iconográfico de Sor Juana también revela una clara función metapoética, pues se trata de un perfecto ejemplo de demostración teórica y práctica de cómo debía entenderse la literatura y, en concreto, la creación poética. La coherencia estructural y compositiva que nos muestra pedagógicamente Sor Juana se convierte en toda una lección magistral en la que podemos aprender cómo surge y se elabora un texto poético manteniendo una estrecha relación entre todos y cada uno de sus componentes, que se traduce en una perfecta confabulación entre el tema, el tono, el estilo, el metro, etc.

6. Sor Juana se incorpora con este tipo de composiciones a ese espíritu desmixtificador del Barroco que subvierte los valores de la poesía iconográfica, que había ensimismado, durante tantos años, a un sinfin de artistas que habían agotado prácticamente las posibilidades

No he pretendido recoger todos y cada uno de los recursos estilisticos que ha empleado Sor Juana en su poema, sino tan sólo los más importantes de acuerdo con la finalidad de su retrato literario. Asi, pues, sirva la relación que he hecho sólo para recapitular de forma simplificada aquellos tropos y figuras retóricas más reiteradas y eficaces en su poema para los propósitos expresivos de Sor Juana.

Esto me permitiria revisar la clasificación sin matices de Sor Juana como una poeta enclavada en el grupo de poetas culteranos. Con esta manera de proceder, Sor Juana nos sitúa, pues, en el más refinado y elegante conceptismo, de lo que se colige que estamos equivocados cuando se afirma, sin más, que nuestra poeta es la más genuina representante del culteranismo en la literatura Hispanoamericana, puesto que se toma como base, y en cierto modo se perpetúa, una errada distinción entre conceptismo y culteranismo. Como se ha podido apreciar, el conceptismo es la base común de nuestra poeta, como lo era también de Quevedo y de Góngora, en contra de lo que secularmente se ha venido sosteniendo. Sobre 
expresivas del motivo e, incluso, del género literario. Sor Juana logra invertir estéticamente los prestigios que dominaban la tradición literaria del poema iconográfico, cuyos primorosos rasgos eran empleados, según convenía, desde la finalidad del ornato o desde la pretensión sarcástica. Nuestra poeta rechazaba, pues, una estética convencional (la del retrato femenino según el canon tradicional, sobre todo el petrarquista) y creaba otra, dentro de la genérica creación satírico-burlesca, que, sin duda, contribuía al florecimiento de toda su poesía.

Este poema no es ni debe concebirse como una concesión marginal u ocasional a un género y un estilo apenas practicado por Sor Juana, sino que debemos entenderlo como una creación que reafirma su trayectoria poética, que dista -como se sabe- de ser unilateral y de estar anclada en una única parcela de la creación literaria. En este poema se aprecian y se reafirman los rasgos literarios que, de forma inequívoca, nos sugieren el proceder creativo de su autora, incluido el aliento de su cultísimo Primero sueño.

El fruto de la ligerísima comparación entre el poema de Sor Juana y el de Polo de Medina tampoco podría deparar demasiadas sorpresas. Según vimos, la mexicana tuvo presente el citado texto del murciano (aparte de su Fábula de Apolo y Dafne y, de una forma más genérica todo su quehacer poético en clave satírico-burlesca; del mismo modo que tampoco sería muy dificil no hallar vestigios de esa misma, y, ya entonces, larga tradición contrafactista del retrato literario o de la descriptio femenina que conformaron los antipetrarquistas) como ella misma reconoce explícitamente. En este sentido, era lógico que la joven poeta buceara sobre todo en aquellos autores que se habían convertido en santo y seña de la parodia petrarquista en relación con el retrato femenino. $\mathrm{Y}$, así, su anhelo poético la llevó hasta la más genuina creación antipetrarquista, la de Francisco de Quevedo, en la que habia bebido Jacinto Polo de Medina. Pero no lo sigue a pies juntillas, ni para imitarlo ni para parodiarlo satíricamente, sino que se trata, más que de imitación paródica, de mimética inventio. Sor Juana crea su poema inspirándose en toda la tradición literaria que tan bien conocía, y siguiendo sus propios pasos en el género poético, con el fin de responder a su nuevo objetivo literario: ofrecer una muestra en negativo de lo que había cultivado tantas veces, y tan extraordinariamente, en positivo, el retrato literario; o, dicho de otra forma, la vis poética de Sor Juana necesitaba experimentarse, probarse en la vertiente literaria de la burla dentro de los cauces del retrato poético, cuyos parámetros rectos tenía ya tan trillados. Y no cabe duda de que nuestra autora consiguió su propósito, pues, no sólo demostró y confirmó su dominio del tema en el terreno burlesco, sino que en ese dificil espacio literario logró ofrecer nuevas perspectivas a un motivo que andaba ya demasiado manido, consiguiendo incluso elevar estéticamente la poesía satírico-burlesca a través de su magnifico poema iconográfico.

esta cuestión puede verse, entre otros trabajos, los siguientes: A. Collard, Nueva poesia. Conceptismo, culteranismo en la crítica española, Madrid, Castalia, 1967; F. Lázaro Carreter, "Sobre la dificultad conceptista", en Estilo barroco y personalidad creadora, Madrid, Cátedra, 1984", pp. 13-43; R. Menéndez Pidal, "Obscuridad, dificultad entre culteranos y conceptistas", en Castilla, la tradición, el idioma, Madrid, Espasa-Calpe, $1966^{4}$, pp. 217-230; F. Monge, "Culteranismo y conceptismo a la luz de Gracián", en Homenaje. Estudios de filologia e historia literaria lusohispanas e iberoamericanas, La Haya, Goor Zonen, 1966, pp. 355-381; E. Orozco, "Caracteristicas del siglo XVII", en Historia de la Literatura Española, II, Renacimiento y Barroco (dir.) J. Ma Díez Borque, Madrid, Taurus, 1980, pp. 391-522; A. A. Parker, "La agudeza en algunos sonetos de Quevedo. Contribución al estudio del conceptismo", en Estudios dedicados a Menéndez Pidal, Madrid, CSIC, 1952, III, pp. 345-360; M. Blanco, Les rhétoriques de la pointe. Baltasar Gracián et le conceptisme en Europe, Paris, Champion, 1992. 
En este ovillejo Sor Juana nos revela que su capacidad como retratista no se reduce sólo al ámbito de las composiciones iconográficas de alabanza, sino que también en este terreno más controvertido y difícil para el realce propio sobresale con una fulgurante brillantez. El retrato satírico-burlesco de Lisarda pone de manifiesto que la poeta mexicana también ha logrado, una vez más, la perfecta simbiosis entre la pintura y la poesía que le ha permitido crear una imagen perfectamente degradada de la belleza ideal femenina, y no por ello menos paradigmática que cualquiera de los ejemplos que ella misma había moldeado en tono serio. Por lo tanto, podemos afirmar que la maestría como retratista de Sor Juana se evidencia desde cualquiera de las dos perspectivas adoptadas en la creación del poema iconográfico: la del retrato lírico o la del retrato satírico-burlesco. La figura realzada, en todo caso, es siempre la de la propia figura demiúrgica, nuestra poeta-pintora.

La pretensión de Sor Juana de conseguir un retrato literario amparándose en la coartada que le facilita el troquel del ut pictura poesis sitúa su pretensión burlesca en los antípodas de las convenciones del género, pero en ningún momento abraza la misoginia literaria que le hubiera facilitado su labor creadora. Así, podemos comprobar cómo no utiliza ninguna de las formas del disfemismo, que rehúye el soez vulgarismo y la palabra malsonante, que no acude al ámbito animal o vegetal, habitualmente convertido en un arsenal de imágenes groseras; en ningún momento la imagen degradada que ha logrado para cada una de las partes del cuerpo de Lisarda supone una sugerencia chocarrera ni aplebeyada; también se aprecia que Sor Juana no se centra en las partes y órganos inferiores de la mujer, sino que se recrea en aquellos miembros del cuerpo femenino más tópicos, evitando toda alusión a las funciones orgánicas primarias o en las miserias fisicas del cuerpo corruptible ${ }^{30}$. La burla del paradigma del ideal de belleza femenina supone una cierta misoginia genérica, pero siempre indulgente, del mismo modo que su modélico poeta cordobés, don Luis de Góngora, quien nunca siguió los parámetros literarios de la feroz misoginia marcada por Quevedo ${ }^{31}$. El retrato de Lisarda resulta burlesco y grotesco, refleja una verdadera parodia o caricatura del ideal de belleza femenina, pero, en ningún caso, pensaríamos que Sor Juana -como hiciera Quevedo en innumerables ocasiones- ensucia ni envilece a la mujer.

La conjunción de todos los procedimientos que he venido señalando conforman la base conceptística que sustenta la creación poética de Sor Juana con el fin de provocar en su finalidad última una ruptura de sistemas más complejos o, si se quiere, de transgredir diversas tradiciones que convergen en nuestro poema: el petrarquismo y la tradición literaria que ha venido ensalzando el ideal de belleza femenina, la tradición del poema iconográfico que ha visto cómo se han invertido sus parámetros rectos en una vertiente o realización burlesca, la tradición misógina, puesto que Sor Juana ha conseguido subvertir el ideal de belleza femenina sin caer en los límites de la misoginia literaria. Y si -con palabras de Aurora Egido-

30 Acerca de la topica habitual en la poesía satírico-burlesca de carácter misógino, véase los estudios sobre Quevedo de A. Mas, La caricature de la femme du mariage et de l'amour dans l'aeuvre de Quevedo, Paris, Ediciones Hispano-Americanas, 1957; I. Arellano, Poesía satírico burlesca de Quevedo, op. cit., pp. 74-75, 164-175, 250-268 mujer, La obra poética de Don Luis de Góngora, op. cit., pp. 47-54. 
"decir de otra manera en poesía es decir otra cosa y los cambios introducidos en el sistema expresivo (verba) alteraban claramente su significado (res)" 32 , no cabe la menor duda de que Sor Juana está ofreciendo nuevas materias poéticas con su personal modo de escribirlas, está abriendo el tema del retrato literario a nuevos y distintos cauces que van desde la transgresión, en forma de sátira humorística, a la función metapoética. Desde este punto de vista, se puede afirmar, sin duda, que el poema de Sor Juana, en virtud de su transgresora propuesta, está ofreciendo nuevas perspectivas a viejos códigos poéticos ${ }^{33}$.

Si se admite, con S.G. Carullo ${ }^{34}$, que en los poemas iconográficos en tono serio de nuestra escritora, junto a la exaltación de la figura retratada, se producía, por el panegírico que hace la escritora del arte y por la conseguida espiritualización de la realidad, el ennoblecimiento de su propia figura como artista, también se debería admitir que, con nuestro ovillejo, la elaboración de una figura retratada que degrada hiperbólicamente el ideal de belleza femenina, también supone la exaltación de dicha figura por cuanto se ha convertido en un paradigma de la imagen satírico-burlesca de la mujer, y por cuanto que tampoco están ausentes los principios teóricos, pictóricos y poéticos que sustentan la composición en sí misma y su esperpéntico bosquejo femenino; por ello se puede afirmar que la elaboración de este retrato satírico-burlesco, este modélico contrafacta supone también el enaltecimiento de nuestra artista (máxime, cuando en ningún momento se pretende exaltar a la retratada, como sí ocurría en los poemas iconográficos serios) y la reafirmación de su singularidad literaria, puesto que con este poema ha conseguido poner de manifiesto su capacidad transgresora frente a la tradición literaria, su riqueza intelectual al apoyarse en un coherente discurso teórico literario y pictórico -incorporado, además, al propio poema- y su habilidad creativa que se traduce definitivamente en la exaltación de su propio nombre poético, enfáticamente subrayado con su lapidaria rúbrica en el último verso del poema.

\section{PERO IN ČOPIČ SOR JUANE INÉS DE LA CRUZ}

V članku se avtor ukvarja s primerjavo pesniškega portreta Lisarde mehiške redovnice in pesnice Sor Juane Inés de la Cruz, in pesniškega portreta Terese (Tertuliana) španskega pesnika iz Murcie, Jacinta Pola De Medine. Oba pesnika, živeča v 17. stoletju, sta gojila v tistem času popularno pesniško obliko imenovano pesniški portret. Pri obeh pesmih, ki ju obravnava članek, gre za ironiziranje oz. za parodijo na poveličevanje ženske lepote, ki se je v pesniških portretih tistega časa pojavljala kot glavna tema. Avtor razčleni podobnosti in razlike med obema pesmima in ugotavlja, da gre Sor Juana Inés de la Cruz še korak dlje od Pola De Medine. Medtem ko ta ostaja pri parodiranju ideala ženske lepote, Sor Juana krši ustaljeno pesniško normo tudi po vsebinski in po formalni plati, obenem pa se sprašuje o svojem poslanstvu in se tako, namesto dialoga med pesnikom in njegovo muzo obrača neposredno na bralca.

32 A. Egido, "La hidra bocal...", art. cit., p. 101.

33 En este sentido, hay que subrayar de nuevo las palabras de E. Bergmann al señalar que el retrato poético se corresponde con el género epistemológico y que, en realidad, nos ofrece -como en este caso- una imagen de la propia poeta "contemplando su propio proceso creativo e imaginativo en términos más literarios que plásticos"; $y$, más adelante, afirma que lo que termina exponiéndose es la "frustración de poetizar", "y lo que se presentaba como esbozo del 'retrato del autor', del escepticismo del poeta frente al propósito de pintar, es el tema central de los 'Ovillejos", art. cit., pp. 231-236.

34 S. G. Carullo, El Retrato Literario..., ob. cit., pp. 148-150. 